\title{
Gas Chromatographic Determination of Phosphorus-Containing Pesticide Metabolites via Benzylation
}

\author{
Christian G. Daughton, ${ }^{1}$ Alasdair M. Cook, ${ }^{2}$ and Martin Alexander ${ }^{*}$ \\ Laboratory of Soil Microbiology, Department of Agronomy, Cornell University, Ithaca, New York, 14853
}

\begin{abstract}
Mono- and di-protic alkyl and aryl phosphates, phosphonates, and thio analogues were determined in spiked samples of bacterial growth medium and human urine using a new procedure with a detection limit of less than 2 pmol each. The acids were fully protonated by passing the aqueous samples through BioRad AG 50W-X8 $\left(\mathrm{H}^{+}\right)$resin and dried thoroughly belore refluxing with 3 -benzyl-1-p-tolyttriazene in acetone. The benzyl esters that formed partitioned quantitatively into cyclohexane and were determined by gas-liquid chromatography with a flame-photometric detector (phosphorus mode) and a glass column (5\% OV-210 on $80 / 100$ mesh Gas Chrom Q). Linear recovery curves were obtained. Inorganic orthophosphate did not interfere with urine analysis, although it could be easily removed by $\mathrm{Ca}(\mathrm{OH})_{2}$ precipitation.
\end{abstract}

Ionic alkyl and aryl phosphates, phosphonates, and thio analogues are metabolites of organophosphorus pesticides and several other categories of economically important chemicals (1). These compounds can be determined on a class basis as inorganic orthophosphate $\left(\mathrm{P}_{\mathrm{i}}\right)$ after wet ashing (2). However, no single method is available for the routine identification or quantitation of these compounds, especially diprotic alkylphosphonates, in biological or abiotic samples. Most of the chromatographic methods have been designed for dialkyl phosphates and thiophosphates. These techniques involve esterification with diazoalkanes and determination of the alkyl

${ }^{1}$ Present address, Sanitary Engineering Research Laboratory, University of California, 112 RFS, 47th and Hoffman Blvd., Richmond, Calif. 94804

${ }_{2}^{2}$ Present address, Mikrobiologisches Institut, ETH Zentrum, $\mathrm{CH}-8092$ Zürich, Switzerland. esters by gas-liquid chromatography (GLC) (3, and references therein). All of these methods have suffered from a key weakness: the unfavorable partitioning of the highly polar dialkyl phosphates into the extraction solvent (3). Indeed, recovery of dialkyl phosphates from urine has been at best semiquantitative $(4,5)$, and the samples required extensive cleanup (6). Furthermore, the techniques available for determining the extremely polar non-esterified alkylphosphonates are few. Jakob et al. (7) developed a separation method for several ionic alkylphosphonates in water, but the procedure was lengthy and the detection limits were poor. Phenylphosphonates in urine have been amylated and separated by GLC, but many interferences were encountered (8).

We report here a method for identifying and quantitating alkyl and aryl phosphates, phosphonates, and thio analogues in biological samples by GLC of the benzyl esters formed with 3-benzyl-1-p-tolyltriazene (BTT). This derivatizing reagent has been proposed for the determination of ionic dimethyl phosphate (9).

\section{EXPERIMENTAL}

Gas-Liquid Chromatography. A Perkin-Elmer 3920B gas-chromatograph equipped with a flame-photometric detector (phosphorus mode) was used. The 0.25 -in. o.d. glass column ( 6 $\mathrm{ft} \times 2-\mathrm{mm}$ i.d., treated with $5 \% \mathrm{w} / \mathrm{v}$ dimethyldichlorosilane in toluene) was packed with $5 \%$ OV-210 on $80 / 100$ mesh Gas Chrom $\mathrm{Q}$ and vapor-phase deposited with Carbowax 20M (10). The glass inlet liner was also treated with dimethyldichlorosilane. The operating conditions were: column oven temperature programmed from $170^{\circ} \mathrm{C}$ at $16^{\circ} \mathrm{C}$ per min to $225^{\circ} \mathrm{C}$ for $4 \mathrm{~min}$; injector, 250 ${ }^{\circ} \mathrm{C}$; detector, $250{ }^{\circ} \mathrm{C}$; He, $30 \mathrm{~mL} / \mathrm{min}_{\text {; }}$ air, $109 \mathrm{~mL} / \mathrm{min} ; \mathrm{H}_{2}, 70$ $\mathrm{mL} / \mathrm{min}$. Isothermal determinations were at $225^{\circ} \mathrm{C}$.

Reagents and Compounds. Technical grade BTT (Aldrich Chemical Co., Metuchen, N.J.) (Caution: BTT is a suspect carcinogen!) was recrystallized from petroleum ether using 2,- 
Table I. Ionic Phosphoric Compounds

\begin{tabular}{|c|c|c|}
\hline iation & chemical name & formula \\
\hline 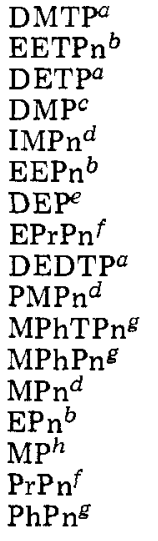 & $\begin{array}{l}O, O \text {-dimethyl hydrogen phosphorothioate } \\
O \text {-ethyl hydrogen ethylphosphonothioate } \\
O, O \text {-diethyl hydrogen phosphorothioate } \\
O, O \text {-dimethyl hydrogen phosphate } \\
O \text {-isopropyl hydrogen methylphosphonate } \\
O \text {-ethyl hydrogen ethylphosphonate } \\
O, O \text {-diethyl hydrogen phosphate } \\
O \text {-ethyl propylphosphonate } \\
O, O \text {-diethyl hydrogen phosphorodithioate } \\
O \text {-pinacolyl hydrogen methylphosphonate } \\
O \text {-methyl hydrogen phenylphosphonothioate } \\
O \text {-methyl hydrogen phenylphosphonate } \\
\text { dihydrogen methylphosphonate } \\
\text { dihydrogen ethylphosphonate } \\
O \text {-methyl dihydrogen phosphate } \\
\text { dihydrogen propylphosphonate } \\
\text { dihydrogen phenylphosphonate }\end{array}$ & $\begin{array}{l}\left(\mathrm{CH}_{3} \mathrm{O}\right)_{2} \mathrm{P}(\mathrm{S}) \mathrm{OH} \\
\left(\mathrm{CH}_{3} \mathrm{CH}_{2} \mathrm{O}\right) \mathrm{CH}_{3} \mathrm{CH}_{2} \mathrm{P}(\mathrm{S}) \mathrm{OH} \\
\left(\mathrm{CH}_{3} \mathrm{CH}_{2} \mathrm{O}\right)_{2} \mathrm{P}(\mathrm{S}) \mathrm{OH} \\
\left(\mathrm{CH}_{3} \mathrm{O}\right)_{2} \mathrm{P}(\mathrm{O}) \mathrm{OH} \\
{\left[\left(\mathrm{CH}_{3}\right)_{2} \mathrm{CHO}\right] \mathrm{CH}_{3} \mathrm{P}(\mathrm{O}) \mathrm{OH}} \\
\left(\mathrm{CH}_{3} \mathrm{CH}_{2} \mathrm{O}\right) \mathrm{CH}_{3} \mathrm{CH}_{2} \mathrm{P}(\mathrm{O}) \mathrm{OH} \\
\left(\mathrm{CH}_{3} \mathrm{CH}_{2} \mathrm{O}\right)_{2} \mathrm{P}(\mathrm{O}) \mathrm{OH} \\
\left(\mathrm{CH}_{3} \mathrm{CH}_{2} \mathrm{O}\right) \mathrm{CH}_{3} \mathrm{CH}_{2} \mathrm{CH}_{2} \mathrm{P}(\mathrm{O}) \mathrm{OH} \\
\left(\mathrm{CH}_{3} \mathrm{CH}_{2} \mathrm{O}\right)_{2} \mathrm{P}(\mathrm{S}) \mathrm{SH}_{2} \\
{\left[\left(\mathrm{CH}_{3}\right)_{3} \mathrm{CCH}(\mathrm{CH}) \mathrm{O}\right] \mathrm{CH}_{3} \mathrm{P}(\mathrm{O}) \mathrm{OH}} \\
\left(\mathrm{CH}_{3} \mathrm{O}\right) \mathrm{C}_{6} \mathrm{H}_{3} \mathrm{P}(\mathrm{S}) \mathrm{OH} \\
\left(\mathrm{CH}_{3} \mathrm{O}\right) \mathrm{C}_{6} \mathrm{H}_{5} \mathrm{P}(\mathrm{O}) \mathrm{OH} \\
\mathrm{CH}_{3} \mathrm{P}(\mathrm{O})(\mathrm{OH})_{2} \\
\left.\mathrm{CH}_{3} \mathrm{CH} \mathrm{PH}_{2} \mathrm{P}\right)(\mathrm{OH})_{2} \\
\mathrm{CH}_{3} \mathrm{OP}(\mathrm{O})(\mathrm{OH})_{2} \\
\mathrm{CH}_{3} \mathrm{CH} \mathrm{CH}_{2} \mathrm{P}(\mathrm{O})(\mathrm{OH})_{2} \\
\mathrm{C}_{6} \mathrm{H}_{5} \mathrm{P}(\mathrm{O})(\mathrm{OH})_{2}\end{array}$ \\
\hline
\end{tabular}

${ }^{a}$ American Cyanamid Company, Agricultural Division, Princeton, N.J. b Stauffer Chemical Co., Richmond, Calif. $c$ Pfaltz \& Bauer, Inc., Stamford, Conn. d Chemical Systems Laboratory, Aberdeen Proving Ground, Md. $e$ Eastman Organic Chemical Division, Rochester, N.Y. ${ }^{\prime}$ FMC Corporation, Middleport, N.Y. $g$ Velsicol Chemical Corp., Chicago, Ill. ${ }^{h}$ Sigma Chemical Co., St. Louis, Mo. (di-monocyclohexylammonium salt). 'i Potassium salts.

2,4-trimethylpentane as a co-solvent at $-20^{\circ} \mathrm{C}$, after solvation at $23^{\circ} \mathrm{C}$, which yielded an orange mother liquor. The resultant colorless crystals were dried at $23^{\circ} \mathrm{C}$ under dry $\mathrm{N}_{2}$. The working solution of $0.25 \mathrm{M} \mathrm{BTT}$ in acetone could be stored at $-20^{\circ} \mathrm{C}$ for at least 6 months (Note: BTT is heat sensitive).

The organophosphorus compounds, their abbreviations, formulas, and sources are given in Table I. Analyses have been reported for MPn, IMPn, PMPn, EPn, and EEPn (Daughton et al., submitted) and for MPhPn and PhPn (Cook et al., submitted). Stock analytical standards were prepared at $4.0 \mathrm{mM}$ in acetone and stored at $-20^{\circ} \mathrm{C}$.

Glassware. Glassware was cleaned by overnight steeping in $5 \mathrm{M} \mathrm{HNO} \mathrm{H}_{3}$ followed by thorough rinsing in distilled deionized water.

Sample Preparation. Aqueous samples (of at least $2 \mathrm{~mL}$ ) containing bacterial protein (e.g., cell extracts) were treated at $4^{\circ} \mathrm{C}$ by addition of known volumes of $70 \% \mathrm{w} / \mathrm{w}$ perchloric acid. The precipitated protein was removed after $10 \mathrm{~min}$ by centrifugation at $40000 \mathrm{~g}$ for $20 \mathrm{~min}$ at $4^{\circ} \mathrm{C}$. The supernatant fluid was neutralized with cold $\mathrm{KOH}$, and the resultant $\mathrm{KClO}_{4}$ was removed by centrifugation at $10000 \mathrm{~g}$ for $10 \mathrm{~min}$ at $4{ }^{\circ} \mathrm{C}$. Suspensions of bacteria in growth medium were either centrifuged or, where possible, passed through $0.2-\mu \mathrm{m}$ pore diameter membrane filters to obtain extracellular fluid.

Human urine samples $(5 \mathrm{~mL})$ were collected in the morning, and they were treated with $0.5 \mathrm{~g}$ of $\mathrm{Ca}(\mathrm{OH})_{2}(11)$ and, after 10 $\mathrm{min}$, filtered through $0.2-\mu \mathrm{m}$ pore diameter Nuclepore membrane filters to remove precipitated $\mathrm{P}_{\mathrm{i}}$.

All acidic samples were adjusted to about $\mathrm{pH} 7$ with $1 \mathrm{M} \mathrm{NaOH}$; all $\mathrm{pH}$ measurements were done with a $\mathrm{pH}$ meter. Spiked samples were prepared by adding appropriate amounts of the analytical standards (in acetone) with a high-pressure syringe to a dry vessel, the acetone was taken to dryness with $\mathrm{N}_{2}$, and the measured portion of the aqueous sample was added.

Derivatization. Prepared samples ( 2 to $4 \mathrm{~mL}$ ) were passed through columns made from 6 in. $\times 7-\mathrm{mm}$ o.d. Pasteur disposal glass pipets, each plugged at the stricture with glass wool and packed with 0.7 to $1.0 \mathrm{~g}$ of BioRad AG 50W-X8 50-100 mesh resin $\left(\mathrm{H}^{+}\right)$(BioRad Laboratories, Richmond, Calif.). To facilitate the packing, the resin needed to be slightly dried at $120^{\circ} \mathrm{C}$ for 30 min or at room temperature for several days. The first 10 to 15 drops of column effluent were discarded, and a measured portion $(50 \mu \mathrm{L}$ to $1.0 \mathrm{~mL})$ of the subsequent effluent was added to a $9-\mathrm{mL}$ screw-cap glass vial. The samples were taken to dryness in the vials at $60^{\circ} \mathrm{C}$ under a gentle stream of dry $\mathrm{N}_{2}$. To each cooled residue was added the BTT reagent in an amount equivalent to half the volume of the sample that had been taken to dryness. The vials were sealed with Teflon-lined screw caps (Arthur $\mathrm{H}$. Thomas Co., Philadelphia, $\mathrm{Pa}$.) and the solution refluxed for at least $20 \mathrm{~min}$ by partially submerging the vials in a water bath at
60 to $70^{\circ} \mathrm{C}$. The organic phase was then concentrated to near dryness (less than $25 \mu \mathrm{L}$ ) under dry $\mathrm{N}_{2}$, and 0.5 or $1.0 \mathrm{~mL}$ of $\mathrm{NaCl}$-saturated distilled water and 4 drops of $6.25 \mathrm{M} \mathrm{HCl}$ were added. The contents were gently mixed until the excess BTT was consumed (as indicated by the lack of gas evolution), and then the solution was extracted by vigorous shaking with 1.0 or $2.0 \mathrm{~mL}$ of cyclohexane (spectrographic grade). The organic phase was removed with a Pasteur pipet and dried by passage through a Pasteur glass pipet containing anhydrous $\mathrm{Na}_{2} \mathrm{SO}_{4}$ and stored at $-20^{\circ} \mathrm{C}$ until analysis. The choice of column effluent sample size and the choice of water and cyclohexane volumes depend only on the final concentrations of benzyl esters desired in the organic phase.

Mass spectral identification of the benzyl esters was done on a $1.5 \mathrm{~m} \times 2$-mm i.d. glass column packed with $3 \%$ QF-1 on $80 / 100$ mesh Gas Chrom Q that was programmed from 140 to $225^{\circ} \mathrm{C}$ at $15^{\circ} \mathrm{C} / \mathrm{min}$ with helium as the carrier gas. A Finnigan 3300 Quadrupole mass spectrometer, with Systems Industries 150 Data System, was operated with charge exchange (with methane) at a source pressure of $133 \mathrm{~Pa}$ for the benzyl esters of MPn, DMP, and MP or with electron ionization $(70 \mathrm{eV})$ for DEP.

\section{RESULTS AND DISCUSSION}

Derivatization. The benzylation of the phosphoric acids by BTT proceeds according to:

$$
\begin{gathered}
\mathrm{RR}^{\prime} P(X) X^{\prime} \mathrm{H}+\mathrm{O}-\mathrm{CH}_{2}-\mathrm{NHN}=\mathrm{N}-\mathrm{O}-\mathrm{CH}_{3} \longrightarrow \\
\mathrm{RR}^{\prime} P(x) x^{\prime} \mathrm{CH}_{2}-\mathrm{O}+\mathrm{N}_{2}+\mathrm{H}_{2} \mathrm{~N}-\mathrm{O}-\mathrm{CH}_{3}
\end{gathered}
$$

where $\mathrm{R}=$ alkoxy or hydroxy, $\mathrm{R}^{\prime}=$ alkoxy, alkyl, or aryl, and $\mathrm{X}$ and $\mathrm{X}^{\prime}=\mathrm{S}$ or $\mathrm{O}$. The acids must be protonated for the reaction to proceed, and the residue must be dry. The reaction was complete within 15 min for samples that did not yield residue sufficient to cover the bottoms of the vials. Refluxing for at least $3 \mathrm{~h}$ had no adverse effect. Protonation of the acids was accomplished most effectively by equilibration with the strong cation-exchange resin in the hydrogen form. A simpler means of acidification of samples with mineral acids (e.g., $\mathrm{HCl}$ ) gave poorer yields of benzyl esters but served to demonstrate that no benzylation occurred for the extremely polar compounds (e.g., MPn) at samples whose $\mathrm{pH}$ values were above 3.5 prior to drying.

The initial 10 to 15 drops of effluent from the dried resin column were discarded because the apparent sample concentration was found to be artificially increased. The enhanced concentration effect of the initial effluent correlated 


\begin{tabular}{|c|c|c|c|c|}
\hline \multicolumn{5}{|c|}{ Table II. Ionic Phosphoric Compounds: Retention Times } \\
\hline no. & benzyl ester & $M_{\mathrm{r}}$ & $t_{R}, \min ^{a}$ & $t_{R}$, rel \\
\hline 1 & $O$-benzyl & 232.24 & 1.97 & 0.7 \\
\hline 2 & O-benzyl & & & \\
\hline 3 & $O$-benzy & & & \\
\hline & $O \cdot$ ben & & & \\
\hline 5 & $O$-benzyl IMPn & & & 1.0 \\
\hline 6 & $O$-benzyl EEPn & & & \\
\hline & $O$ benz & 24 & & \\
\hline 8 & $O-b$ & & & \\
\hline 9 & $S$-benz & & & 1.2 \\
\hline 10 & $S$-benzyl DEDTP & & & 1. \\
\hline 11 & $S$-benzyl EETPn & & 3. & 1. \\
\hline 12 & $S$-be & & & \\
\hline 13 & $O$-benzyl PMPn ${ }^{b}$ & & 3.78 & 1. \\
\hline 14 & $O$-benzyl MPhTPn & 27 & 4.5 & 1.7 r r \\
\hline 15 & $O$-benzyl MPhPn & 262.24 & 5. & 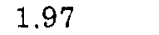 \\
\hline 16 & $O, O$-dibenzyl MPn & 276 & 6. & 2. \\
\hline 17 & $O, O-\mathrm{d}$ & & & \\
\hline 18 & $S$-benzyl MPhTPn & 278 & 6. & 2. \\
\hline 19 & $O, O$-dibe & 292.2 & 6.6 & 2.5 \\
\hline 20 & $O, O$-dibenzyl $\mathrm{PrPn}$ & 304.33 & 6.78 & 2.58 \\
\hline 21 & $O, O$-dibenzyl $\mathrm{PhPn}$ & 338.33 & $--^{c}$ & $--^{c}$ \\
\hline 22 & $\begin{array}{l}O, O, O \text {-tribenzyl- } \\
\text { phosphate }\end{array}$ & 368.38 & 20. & 7.6 \\
\hline \multicolumn{5}{|c|}{$\begin{array}{l}{ }^{a} \text { Non-adjusted retention time. }{ }^{b} O \text {-Benzyl PMPn yields } \\
2 \text { peaks. }{ }^{c} \text { Does not chromatograph with temperature } \\
\text { programming. }\end{array}$} \\
\hline
\end{tabular}

positively with the degree of dehydration of the resin. This was presumably caused by osmotic concentration of the initial effluent by the resin. Subsequent effluent was fully equilibrated and yielded lower, reproducible, and accurate concentrations. Because of the osmotic concentration effect of dried resin, the resin was not used in a batch treatment of the samples, such as that described by Blair and Roderick (11). Alternatively, if the resin was saturated with water before sample application, the initial effluent was diluted, as expected. In addition, low recovery values were obtained when acidic samples were passed through the resin. This necessitated prior neutralization of all samples. The use of 2- to 4-mL samples allowed sufficient sample to be collected from the resin without exceeding the exchange capacity of the quantity of resin used.

$\mathrm{HCl}$ was added to the completed reaction mixture to consume the excess BTT and to force the 4-aminotoluene and other by-products out of the organic extraction phase. A resultant reddish oily residue did not interfere with the extraction.

The structures for four of the benzyl derivatives were confirmed by their mass spectra, for which the two most intense ions are presented for every 14 mass units above $m / z$ 34 (rel intensity >1.0). MPn, 61(10.9), 79(13.4), 91(100.0), 92(14.6), 97(4.2), 107(18.7), 108(2.9), 119(12.1), 127(1.8), 181(5.3), 185(1.9), 276( $\left.\mathrm{M}^{+},--\right)$, 277(4.9). DMP, 84(6.0), 85(6.5), $91(100.0), 92(9.7), 107(3.1), 119(4.1), 127(3.3), 196(1.7)$, 216(M+,--), 217(2.7). MP, 61(1.8), 79(5.3), 91(100), 92(14.3), $107(10.1)$, 113(4.3), 119(10.5), 127(2.1), 137(1.1), 181(6.7), 182(1.5), 201(2.6), 292( $\left.\mathrm{M}^{+},--\right), 293(4.3)$. DEP, 39(12.4), 45(5.4), 51(6.6), 59(6.2), 63(7.4), 65(24.4), 77(13.3), 79(12.7), 89(10.4), 90(17.6), 91(100), 107(67.8), 111(12.3), 118(22.1), 125(20.6), 137(4.7), 138(10.5), 153(9.4), 159(1.5), 187(14.9), 188(10.0), 201(2.1), 215(9.4), 216(3.2), 244( $\left.\mathrm{M}^{+}, 3.5\right)$. These spectra are dominated by that of the benzyl group, the base peak being $m / z=91$ (tropylium ion).

Chromatography. The retention times for the benzyl esters are given in Table II. In gereral, $t_{\mathrm{R}}$ (non-adjusted retention time) increased with $M_{\mathrm{r}}$, with the exception of the $O$-benzyl esters of the thioates, which are not retarded as much as the $S$-benzyl esters; this was expected because of the selective retardation of ketones by OV-210. Formation of the mixed $O$ - and $S$-benzyl isomers of the thioates could be avoided by oxidation of the sample with sodium hypochlorite prior to sample preparation; when this was done, subsequent benzylation yielded only the corresponding phosphate or phosphonate. The $O$-benzyl ester of PMPn yielded two unresolved peaks, presumably a result of its four optical isomers.

Data for $\mathrm{PhPn}$ were not obtained for the temperature program used, but with isothermal operation $\left(225^{\circ} \mathrm{C}\right)$, a peak at $8.5 \mathrm{~min}$ was obtained. The late-eluting dibenzyl esters could be more readily determined isothermally. The inability of small quantities of dibenzyl $\mathrm{PhPn}$ to chromatograph under temperature programing is illustrative of a problem with the stability of the dibenzyl esters in particular. Tribenzyl phosphate would elute only when injected in large amounts (e.g., in untreated urine). These compounds would not chromatograph on stainless steel columns, presumably because of catalytic hydrolysis, although favorable results were obtained with a nickel column (Analabs, Inc., North Haven, Conn.). Severe tailing occurred if the packed glass column was not vapor-phase deposited with Carbowax 20M. The esters are apparently susceptible to hydrolysis by silica. This was presumably the factor that made the determination of these derivatives by reverse-phase high-performance liquid chromatography unsuccessful (Daughton, unpublished data).

Unaltered chromatograms are presented for the benzyl derivatives of representative phosphonates and thiophosphonates (Figure 1A and B) and for phosphates and thiophosphates (Figure 1C); the injected samples contained 50 to $100 \mathrm{pmol}$ of each compound. Only partial resolution was obtained for the benzyl esters of MPhTPn (S-benzyl), EPn, and MPn, for IMPn and EEPn, and for DEP and DMTP ( $S$-benzyl). The separations are of particular interest because no method to date has been applicable to the highly polar diprotic alkyl phosphates and phosphonates, especially MPn, EPn, PrPn, and MP. For example, the extractive/ methylation procedure suggested by Daughton $\mathrm{et}$ al. (3), which uses methyl ethyl ketone/ethyl acetate and ethereal diazomethane, gave recoveries for 2 to $12 \mu \mathrm{M}$ IMPn and for 2 to $10 \mu \mathrm{M}$ PMPn of 84 to $89 \%$ and 91 to $99 \%$, respectively. In contrast, when a solution of $50 \mu \mathrm{M}$ MPn was analyzed, no recovery of MPn was achieved.

The benzylation method, when applied to urinalysis, presented no major problem. The oily residue remaining after sample drying needed to be fully in contact with the BTT reagent to achieve full benzylation. Several solvents were tested for this refluxing step. The ketones, especially acetone, gave the best results. Alcohols completely dissolved the residue but prevented benzylation. When little residue was present, results were favorable with ethyl acetate, diethyl ether, and dichloromethane, but hexane was apparently not polar enough to solvate the phosphorus acids. Solvation of the urine residue was more difficult when the samples were dried at higher temperatures (e.g., $120^{\circ} \mathrm{C}$ ); presumably, lyophilization would make the residue even more amenable to benzylation.

The absence of interfering and extraneous peaks with derivatized urine samples is shown in Figure 2. Injections of $2 \mu \mathrm{L}$ (equivalent to $1 \mu \mathrm{L}$ of untreated urine) only gave a large peak at $20 \mathrm{~min}$, which was presumably, 0,0,0-tribenzyl phosphate, resulting from the large amounts of $P_{i}$ (Figure $2 A$ ) in urine. This benzyl derivative was highly labile and eluted only from a fully conditioned and deactivated column. Treatment of the urine with $\mathrm{Ca}(\mathrm{OH})_{2}$ was fully effective in removing $P_{i}$, as shown when the samples were analyzed at an electrometer setting required for analysis at the detection limit of the other compounds (Figure 2B). There was no noticeable difference between this treated urine blank and a water blank 


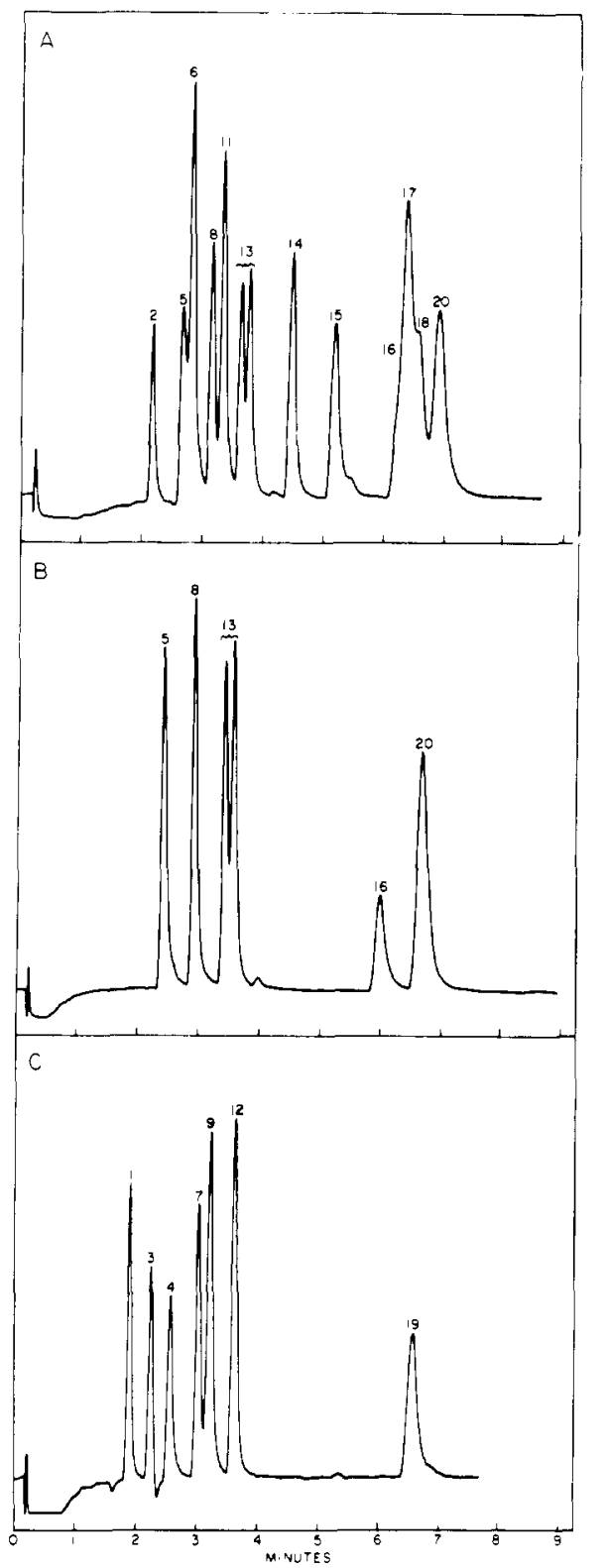

Figure 1. Gas-liquid chromatograms of reaction mixtures after benzylation of some ionic organophosphorus acids. The peaks are identified by the numbers listed in Table II. Conditions: $2-\mu \mathrm{L}$ injections; $6 \mathrm{ft} \times 2$-mm i.d. glass column packed with $5 \%$ OV-210 on $80 / 100$ mesh Gas Chrom Q; temperature programmed from $170^{\circ} \mathrm{C}$ at 16 ${ }^{\circ} \mathrm{C} / \mathrm{min}$ to $225^{\circ} \mathrm{C}$; injector, $250^{\circ} \mathrm{C}$; phosphorus flame-photometric detector, $250^{\circ} \mathrm{C}$; $\mathrm{He}, 30 \mathrm{~mL} / \mathrm{min}$; air, $109 \mathrm{~mL} / \mathrm{min} ; \mathrm{H}_{2}, 70 \mathrm{~mL} / \mathrm{min}$; 50 to $100 \mathrm{pmol}$ of each compounds; chart speed $2 \mathrm{~cm} / \mathrm{min}$

(Figure 2C) treated in parallel.

Studies to determine absolute recovery were not possible because authentic benzyl esters were not available to make reference standards. This is also a problem with all other procedures that depend on quantitative alkylation of analytical standards with diazoalkanes and other alkylation agents (e.g., $3,6,12$ ). Therefore, relative recoveries of several of the acids from spiked urine samples were calculated by comparison with recoveries from water samples treated in parallel. Duplicate urine samples were spiked to final concentrations of 4,8 , and $12 \mu$ M EPrPn, IMPn, PMPn, MPhPn, MPn, and PrPn. Each of these samples was also treated by $\mathrm{Ca}(\mathrm{OH})_{2}$ precipitation.

Recoveries for EPrPn from raw urine and $\mathrm{Ca}(\mathrm{OH})_{2}$-treated urine were 109 and $102 \%$, respectively, when compared to water samples. The values for MPhPn were 91 and $83 \%$, respectively. The recovery curves of $\mathrm{PrPn}$ were linear $\left(r^{2}>\right.$ 0.98 ) for all samples, with the recovery from $\mathrm{Ca}(\mathrm{OH})_{2}$-treated

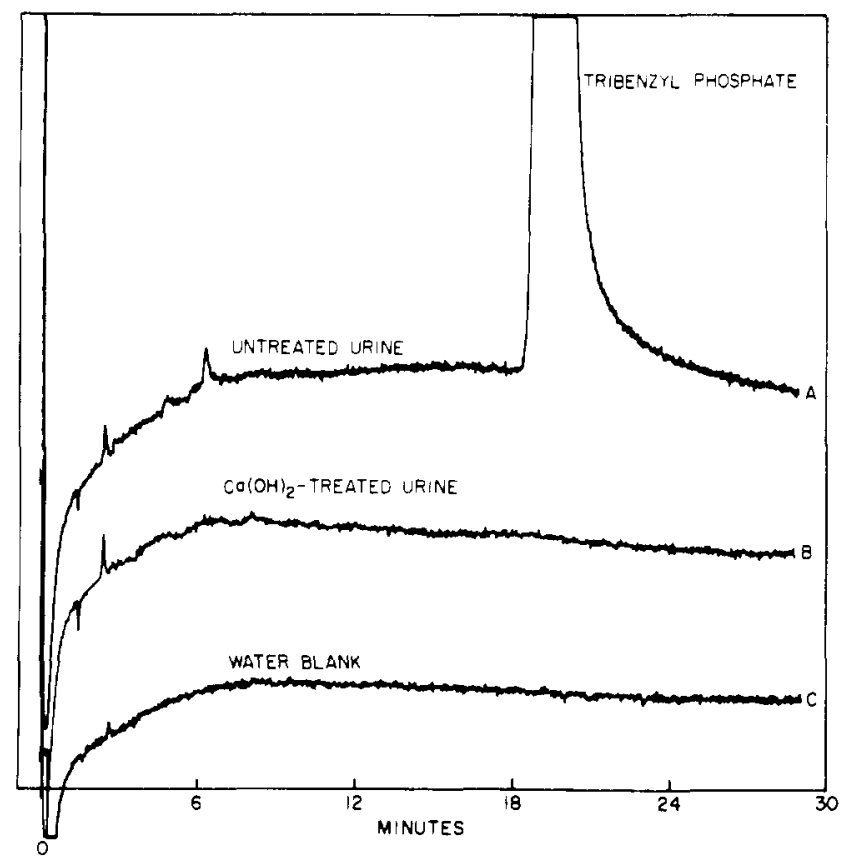

Figure 2. Gas-liquid chromatograms of reaction mixtures after benzylation of $(A)$ untreated urine, $(B) \mathrm{Ca}(\mathrm{OH})_{2}$-precipitated urine, and (C) water. Conditions as in Figure 1; each injection was equivalent to $1 \mu \mathrm{L}$ of urine; chart speed $40 \mathrm{~cm} / \mathrm{h}$; attenuation at level required for detection limit of benzyl esters

urine being about $25 \%$ lower than from untreated urine. A similar significant loss from $\mathrm{Ca}(\mathrm{OH})_{2}$-treated urine was also found for MPn. A portion of the monoalkylphosphonates was presumably precipitated by the calcium. A comparison of recoveries of these diprotic alkylphosphonates with those from water was not possible because these compounds derivatize erratically in samples of low osmolarity.

Under the conditions of sample drying, irreproducible amounts of IMPn and PMPn were hydrolyzed at the alkyl ester linkage yielding MPn, which became the derivatized product. The detection limit for all of the compounds in urine was less than $2 \mathrm{pmol}$ (less than $0.6 \mathrm{ng}$ for each of the benzylated compounds).

The recovery of MPn from spiked suspensions of bacteria was determined for 12 concentrations from 0.13 to $1.0 \mathrm{mM}$. The regression equation for peak heights vs. amount of MPn had a correlation coefficient of 0.996 , compared to 0.998 for the standard curve derived from water. When samples contained excessive amounts of protein, the perchlorate precipitation procedure was satisfactory.

Comparison to Other Procedures. A major problem with the analysis of biological samples for ionic alkyl phosphoric compounds, as their neutral alkyl esters, has been the interference of $\mathrm{P}_{\mathrm{i}}$, which yields $0,0,0$-trialkyl phosphate. We found the precipitation of $\mathrm{P}_{\mathrm{i}}$ with $\mathrm{Ca}(\mathrm{OH})_{2}$ (11) to be highly effective (Figure 2), but some loss of monoalkyl diprotic phosphorus acids was incurred. However, by formation of the benzyl esters, the analysis of 4 to 6 samples was possible before the late-eluting $0,0,0$-tribenzyl phosphate interfered with subsequent injections. By the use of a short precolumn and an automatic switching valve, the tribenzyl phosphate could presumably be vented before entering the analytical column. This would make any urine cleanup totally unnecessary.

The simplicity of the procedure allows for the throughput of more than 20 samples per day. The benzyl groups give a better response than alkyl esters if detection by flame ionization or mass spectrometry is desired, and, more important, the aromaticity greatly enhances the partition coefficients for the esters, allowing for the use of a variety of extraction solvents. Cyclohexane was chosen in this work because of its 
low water solubility and low vapor pressure relative to other possible extraction solvents. The benzyl esters are much less volatile than the alkyl esters, which allows for their more than 10-fold concentration under $\mathrm{N}_{2}$ even from 2,2,4-trimethylpentane with no detectable loss of the benzyl esters. The BTT reagent is much easier, cheaper, and safer to prepare than the diazoalkanes, and it has a longer storage life.

The two major problems with the method are the inconvenience of discarding the initial effluent from the resin column to avoid spurious concentration of the organophosphorus acids and the unavailability of absolute reference standards of the benzyl esters. The latter problem, however, is also characteristic of other procedures that rely on derivatization. This shortcoming could be solved most easily by sample analysis without derivatization, most probably via separation of the unaltered compounds by high-performance liquid chromatography followed by a post-column reaction which would yield a product amenable to absorbance detection (e.g., reduced heterophosphomolybdate). Regardless of the accuracy and precision of a method, quantitation of metabolites in urine is not meaningful because of variations in urine output; the concentration values must be correlated with another variable such as osmolarity of the urine.

\section{ACKNOWLEDGMENT}

We thank T. Wachs for obtaining the mass spectra.

\section{LITERATURE CITED}

(1) Cook, A. M.; Daughton, C. G.; Alexander, M. Appl. Environ. Microbiol. 1978, 36, 668-772.

(2) Cook, A. M.; Daughton, C. G.; Alexander, M. Anal. Chem. 1978, 50 , 1716-1717.

(3) Daughton, C. G.; Crosby, D. G.; Garnas, R. L.; Hsieh, D. P. H. J. Agric. Food Chem. 1976, 24, 236-241.

(4) Kraus, J. F.: Richards, D. M.; Borhani, N. O.; Mull, R.; Kilgore, W. W.; Winterlin, W. Arch. Environ. Contam. Toxicol. 1977, 5, 471-485.

(5) Morgan, D. P.; Hetzler, H. L.; Stach, E. F.; Lin, L. I. Arch. Environ. Contam. Toxicol. 1977, $6,159-173$.

(6) Shafik, T.; Bradway, D. E.; Enos, H. F.; Yobs, A. R. J. Agric. Food Chem. $1973,21,625-629$

(7) Jakob, F.; Park, K. C.; Ciric, J.: Rieman. W. III Talanta 1961, 8, 431-437.

(8) Lores, E. M.; Bradway, D. E. J. Agric. Food Chem. 1977, 25, 75-79.

(9) Shafik, T. M.; Peoples, A. "Abstracts of Papers", 172nd National Meeting of the American Chemical Society, San Francisco, Calif., Aug. 1976: American Chemical Soclety: Washington, D. C., 1976; PEST 103.

(10) Ives, N. F.: Giultrida, L. J. Assoc. Off. Anal. Chem. 1970, 53, 973-977.

(11) Blair, D.; Roderick, H. R. J. Agric. Food Chem. 1976, 24, 1221-1223.

(11) Churchill, F. C., II; Ku, D. N.; Miles, J. W. J. Agric. Food Chem. 1978, $26,1108-1112$. 